\title{
Reducing the Space Footprint of Black Soldier Fly Larvae Waste Treatment by Increasing Waste Feeding Layer Thickness
}

\author{
Saleha Mahmood ${ }^{1 *}$, Amtul Bari Tabinda ${ }^{1}$, Azhar Ali ${ }^{2}$, Christian Zurbrügg ${ }^{3}$ \\ ${ }^{1}$ Sustainable Development Study Center, Government College University, Kachery Road, Lahore, Pakistan \\ ${ }^{2}$ The Urban Unit, 503, Shaheen Complex, Edgerton Road, Lahore \\ ${ }^{3}$ Swiss Federal Institute of Aquatic Science and Technology (Eawag), Zurich, Switzerland
}

Received: 17 March 2020

Accepted: 19 May 2020

\begin{abstract}
Black Soldier Fly Larvae (BSFL) (Hermetia illucens) waste treatment process is a promising solution for reclaiming organic waste which is up to $50 \%$ of municipal waste produced in the developing countries. BSFL operational guidelines issued by EAWAG Switzerland recommend $5-10 \mathrm{~cm}$ thick waste layers for the treatment process requiring large space especially for treating huge quantities of waste. This study explored performance of BSFL waste treatment process for waste feeding layers with thickness between $10-100 \mathrm{~cm}$ on a pilot scale in Pakistan. The key parameters analyzed were, waste layer thickness and 50\% thickness reduction with time, dry matter waste weight reduction and volume reduction which indicated degree of waste treatment. Furthermore, larval weight gain, bio conversion rate (BCR), residue and metabolism were also calculated. Waste layer thickness reduction varied between 68.9 (SD 0.75)-96.7 \% (SD 0.65), waste dry weight reduction 45.2 (SD 5.20)-96.5\% (SD 0.20) and volume reduction was found to be between 64.0 (SD 3.46) and 87.9\% (SD 2.61) for layers with thickness of $10-100 \mathrm{~cm}$. Final larval weight and bioconversion rate ranged between $0.031-0.047 \mathrm{~g}$ and $6.01 \%$ and $9.94 \%$ respectively in different layers. Metabolized waste was more than the residue in all samples except the one with $90 \mathrm{~cm}$ waste layer thickness. This study confirmed that space foot print of BSFL treatment process can be decreased using waste layers with higher thickness than the widely practiced $10 \mathrm{~cm}$ thickness.
\end{abstract}

Keywords: Black Soldier Fly, Larvae, Organic Waste, Developing Countries, Bio Conversion Rate, Space Foot Print, Feeding Layer

*e-mail: salehaamahmood@gmail.com 


\section{Introduction}

Developing countries are facing an incremental problem of municipal solid waste management with the passage of time [1, 2]. Most of such countries including Pakistan followed the practice 'out of sight out of mind' where the collected waste was simply transferred to open spaces available around the settlements [3]. However, with cities growth most of the waste dump sites previously outside of the city got surrounded by dwellings. This forced the authorities to transport the waste further away leading to huge transportation costs. Given the past negative experiences, local residents also started to object to this practice and deny access to the authorities to dump the waste which was not produced in their area but was being brought from other much bigger settlements.

Facing such problems, the authorities have an urgent interest to reduce waste transported for disposal, to reduce transportation costs and save space at disposal sites. Pakistan and countries with similar socioeconomic structure have thousands of scavengers (waste pickers) involved in extracting valuables i.e. recyclables from the waste chain either at door-step, during transport or even at the wild dump sites [4] with focus on the non-organic fraction that is more frequently recycled due to higher economic value. Organic waste recycling is still very limited in low and middle income countries like Pakistan, although the organic fraction in municipal solid waste is around $50-80 \%$ [5-7]. This component is naturally biodegradable but several environmental problems are associated with its unsafe disposal and poor waste management practices like production of leachate, greenhouse gases, wastage of useful nutrients and energy. Moreover, it is hard to compact organic waste through mechanical means thus resulting in poor weight and volumetric reductions even if compacted. Weight and volume reduction of organic waste are important parameters as they identify the amount of space and cost required for collection, transportation and disposal of waste at landfill with different vehicles.

One promising and emerging new recycling process in organic waste management sector is the bioconversion of organic waste through use of Black Soldier Fly Larvae (BSFL), scientifically known as Hermetia illucens [7-9]. This is a non-pest organism of warm and humid regions [10]. It not only reduces weight and volume of organic waste but can also convert it to valuable market products i.e. protein and fat rich animal feed (the larvae) and residue which is helpful in agriculture sector for reducing soil erosion [8, 11-13]. Through BSFL biowaste treatment, maximum $20 \%$ of prepupal biomass conversion could be achieved within almost two weeks with a waste reduction of up to $80 \%$ $[11,14]$. BSFL biowaste treatment technology is better than other recycling and bioconversion technologies as the larvae is environment friendly, the direct GHG emissions are very low with a high potential for global warming reduction [2]. They are more advantageous for the countries facing poor waste management practices and food scarcity. As developing countries lack technical and financial resources to handle waste problem, any natural solution to organic waste problem like BSFL could be of great help. Very few studies reported BSFL waste treatment for mixed municipal organic waste which was first experimented in Costa Rica [15]. The current study was conducted on nonhomogenous waste source i.e. mixed municipal organic waste from fruit and vegetable market.

According to EAWAG guidelines, the recommended Waste Layer Thickness (WLT) for operating a BSFL treatment unit is 5-7 cm [11]. However another guideline suggested that the WLT may even be increased to $20-23 \mathrm{~cm}$ [16]. No research studies or data was found that limit the waste layer thickness for BSFL case except these two guidelines. However, a review paper suggested maximum feeding layer thickness of $5 \mathrm{~cm}$ for 'face fly larvae', $5 \mathrm{~cm}$ for housefly larvae and $7.5-10 \mathrm{~cm}$ for all types of fly larvae [17]. The reasoning given has been creation of anaerobic conditions below these depths thus limiting larval growth. However, no scientific study has been done or results published to date except the one being presented here to assess the larval survival in anaerobic or semi aerobic conditions; at higher depths. Therefore, this is the first study and paper reporting the results of work done with increased waste layer thickness of up to $100 \mathrm{~cm}$. The results of the study once again showed importance of data driven assessment for successful facility designing.

This study focused on treating waste with layers' thickness of 10-100 cm. In case of successful treatment at $100 \mathrm{~cm}$, the space foot print of the process can be decreased 5 folds as compared to $20 \mathrm{~cm}$ thick waste layer.

It has been recommended to use waste stacked in trays above each other to maximize use of limited space [11]. However, use of stacking requires specialized stands, boxes/trays and human resources. In this study, increased thickness of waste layers was used to eliminate the need of specialized infrastructure and handling thus decreasing the required financial resources and investment. Furthermore, as study aimed to develop a model treatment facility to handle large amounts of wastes in hundreds of tons a day, stacking seems not feasible in such case. Increased waste layer thickness would allow handling large amounts of waste in less space. To reduce space requirements/foot print, this study tested if larger waste layer thicknesses could be used for BSFL treatment process.

From organic waste treatment perspective it might be sufficient to reduce the waste amounts significantly using this process to reduce waste burden at dump sites [15] and also, during transportation. Therefore, volumetric waste reduction is also a parameter for evaluating BSFL biowaste treatment efficiency. From waste management perspective, optimizing the growth of larvae is not of main concern as only $2-5 \%$ of 
larvae is required to run a rearing unit [11] for future treatment process. For the purpose of this study, an efficient BSFL treatment was defined as the one that could reduce waste layer thickness, weight and volume effectively in 15 days. During this study WLT, weight and volume reductions were monitored along with larval weight gain, bio conversion rate (BCR), residue and metabolism.

This study addressed the following research question:

Can BSFL waste treatment process work for 10 to $100 \mathrm{~cm}$ thick waste layers? This comprises reduction of WLT in relation to treatment time, 50\% thickness reduction, relationship between increased waste layer thicknesses and dry matter waste weight and volume reduction, bioconversion rate, residue and metabolism.

The objective of this research was to investigate the effect of waste layer thickness on the ability of BSFL to successfully reduce waste quantity.

\section{Material and Methods}

Concrete beds were constructed to receive and treat organic waste using BSFL. Temporary brick walls were used to enclose waste to attain a certain waste height to check viability of waste treatment using BSFL. WLT varied from 10 to $100 \mathrm{~cm}$ in triplicates. The $10 \mathrm{~cm}$ WLT was used as a control sample because this has largely been recommended and used in different studies. BSFL was obtained from a nearby BSF rearing facility maintained by the Urban Unit, a governmental organization based in Lahore, Pakistan. The experiment was performed in a green house shed under ambient temperatures and humidity of $32-40^{\circ} \mathrm{C}$ and $60-80 \%$ respectively.

Organic waste was collected from a fruit-vegetable market, manually sorted and shredded to prepare 10 samples (with triplicates) with average waste density found to be $640 \mathrm{~kg} / \mathrm{m}^{3}$. Some dry husk, decomposing dry leaves and sugar cane bagasse was mixed into the waste as per need in order to maintain moisture content of incoming samples which was found to be between $65-70 \%$ which is ideal for BSFL biowaste treatment $[14,18]$.

\section{Samples Placement}

A concrete base with dimensions $6.34 \mathrm{~m} \times 4.00 \mathrm{~m}$ was constructed. Temporary brick walls covered with plastic sheets were used to isolate samples of varying thicknesses. A $30^{\circ}$ angle inclined ramp led from the base of the bed to the edges to facilitate the migration in to a $20 \mathrm{~cm}$ channel constructed on three sides of the beds for collection of prepupae $[15,16]$. Ten waste samples (in triplicates) were deposited on this concrete base with waste layer thicknesses of $10,20,30,40,50,60,70$, 80,90 and $100 \mathrm{~cm}$. BSFL were initially placed every $10 \mathrm{~cm}$ in the waste layers as the maximum layer thickness was recommended as $10 \mathrm{~cm}$ in the guidelines $[11,16]$ and also as was learned during the training provided by FORWARD/EAWAG before start of the study. After every $10 \mathrm{~cm}$ layer in a sample a defined number of larvae per waste amount were spread. The number of larvae used was in reference with 650,000 larvae per ton of waste as recommended at EAWAG FORWARD project site in Surabaya, Indonesia. Waste and larvae were fed once [19] and samples were mixed once a day using shovels for 15 days. Mixing was introduced in this study and was not found to be practiced in earlier available studies.

\section{BSFL Waste Treatment Efficiency Assessment}

The varying waste layer thicknesses in the samples were measured on daily basis. The surfaces of waste layers were made even using a suitable shovel. Thicknesses were recorded from three different points at the surfaces of the samples using a foot scale. Average of the three recordings was then taken as the thickness of the respective layer for a certain day.

The waste samples were mixed daily (once) for 15 days using a shovel. Mixing was performed in order to keep the sample aerated and discourage formation of anaerobic conditions along with facilitation of even distribution of larvae seeking food. After a period of 15 days of BSFL waste treatment three representative samples of $30 \mathrm{~g}$ each were taken from every waste sample. All BSFL were removed from the samples before analyzing the waste for final moisture content and final dry weight using a drying oven at $105^{\circ} \mathrm{C}$ for 24 hours.

Following parameters were measured during the study. i) Change in waste layer thickness on daily basis ii) Wet and dry weight of waste before and after experiment iii) Larval wet weight before and after experiment iv) Final larval dry weight.

Based on these measured parameters following values were calculated:

\section{Waste Layer Thickness Reducton Efficiency (WTE \%)}

$$
\mathrm{WTE}=((\mathrm{WTi}-\mathrm{WTf}) / \mathrm{WTi}) \times 100
$$

...where:

$\mathrm{WTi}=$ initial thickness of waste samples $(\mathrm{cm})$ $\mathrm{WTf}=$ final thickness of organic waste samples $(\mathrm{cm})$

$$
\text { Waste dry weight reduction efficiency }
$$$$
(\mathrm{WRE} \%)=((\mathrm{Wdi}-\mathrm{R}) / \mathrm{Wdi}) \times 100[20]
$$

...where:

Wdi = initial dry weight of organic waste $(\mathrm{kg})$ $\mathrm{R}=$ final dry weight of organic waste $(\mathrm{kg})$

Volumetric waste reduction efficiency

$$
(\mathrm{VRE} \%)=(\mathrm{Vi}-\mathrm{Vf} / \mathrm{Vi}) \times 100
$$


...where:

$\mathrm{Vi}=$ initial volume of organic waste added $\left(\mathrm{m}^{3}\right)$

$\mathrm{Vf}=$ final volume $\left(\mathrm{m}^{3}\right)$ of organic waste

Initial volume was taken by measuring the three dimensions after adding waste samples to beds. Final volume was noted by measuring dimensions at the end of experiment by placing all the remaining waste (digested and undigested food) in a box. Moisture content (\%) of organic waste was calculated on the basis of waste initial wet weight (Wwi) and final dry weight (Wdf). $\mathrm{R}$ is the final dry weight of organic waste, with

$$
\mathrm{R}=\mathrm{Wwf}-(\mathrm{Wwf} \times \mathrm{MC})
$$

which is calculated on the basis of final wet weight in $\mathrm{kg}$ (Wwf) and moisture content (MC) of organic waste.

\section{BSFL Sampling and Testing}

From the treated waste samples containing residue and larvae, 3 representative samples of 15 BSFL were taken and brought to laboratory. These larvae were then surface dried using tissue paper and weighed to obtain their wet weight. The samples were dried in oven at $105^{\circ} \mathrm{C}$ for 24 hours to obtain dry weight of larvae. Moisture content of larvae was calculated by subtracting dry weight from wet weight.

Bioconversion ratio (BCR \%) was calculated at the end of experiment on the basis of final prepupal biomass (Mpp) on dry basis and total amount of organic waste initially added on dry basis (Wdi) both in kgs [20]

$$
\mathrm{BCR}=((\mathrm{Mpp}-\mathrm{Mi}) / \mathrm{Wdi}) \times 100
$$

$\mathrm{Mi}$ is the initial dry weight of 5 days old larvae which is taken zero, as neonatal larvae have negligible amount of dry weight and most of their body weight was found to be consisting of water. This has been verified through work at EAWAG's FORWARD project site in Surabaya, Indonesia

Metabolized food (M) is a result of larval activity which is calculated on the basis of final prepupal dry weight (Mpp) and Initial \& Final dry weights of the organic waste [21]

$$
\mathrm{M}=((\mathrm{Wdi}-\mathrm{R})-\mathrm{Mpp}) \times 100
$$

Statistical analysis: One way-ANOVA (analysis of variance) followed by Tukey HSD post hoc test was performed to identify honestly significantly different mean values between various treatments with $(\mathrm{p}<0.05)$.

\section{Results and Discussion}

\section{Waste Layer Thickness and Volumetric Reduction}

The general practice of BSFL application suggests using maximum WLT of $5-10 \mathrm{~cm}[11,22]$. In this study, first of its kind in this field BSFL was applied to waste layers with varying thickness between 10 and $100 \mathrm{~cm}$. Fig. 1 shows that WLT reduction varied between $96.7 \%$ (SD 0.67) for $30 \mathrm{~cm}$ and $68.9 \%$ (SD 0.73 ) for $90 \mathrm{~cm}$ thick

\section{Volumetric, Thickness \& Dry Weight Reductions}

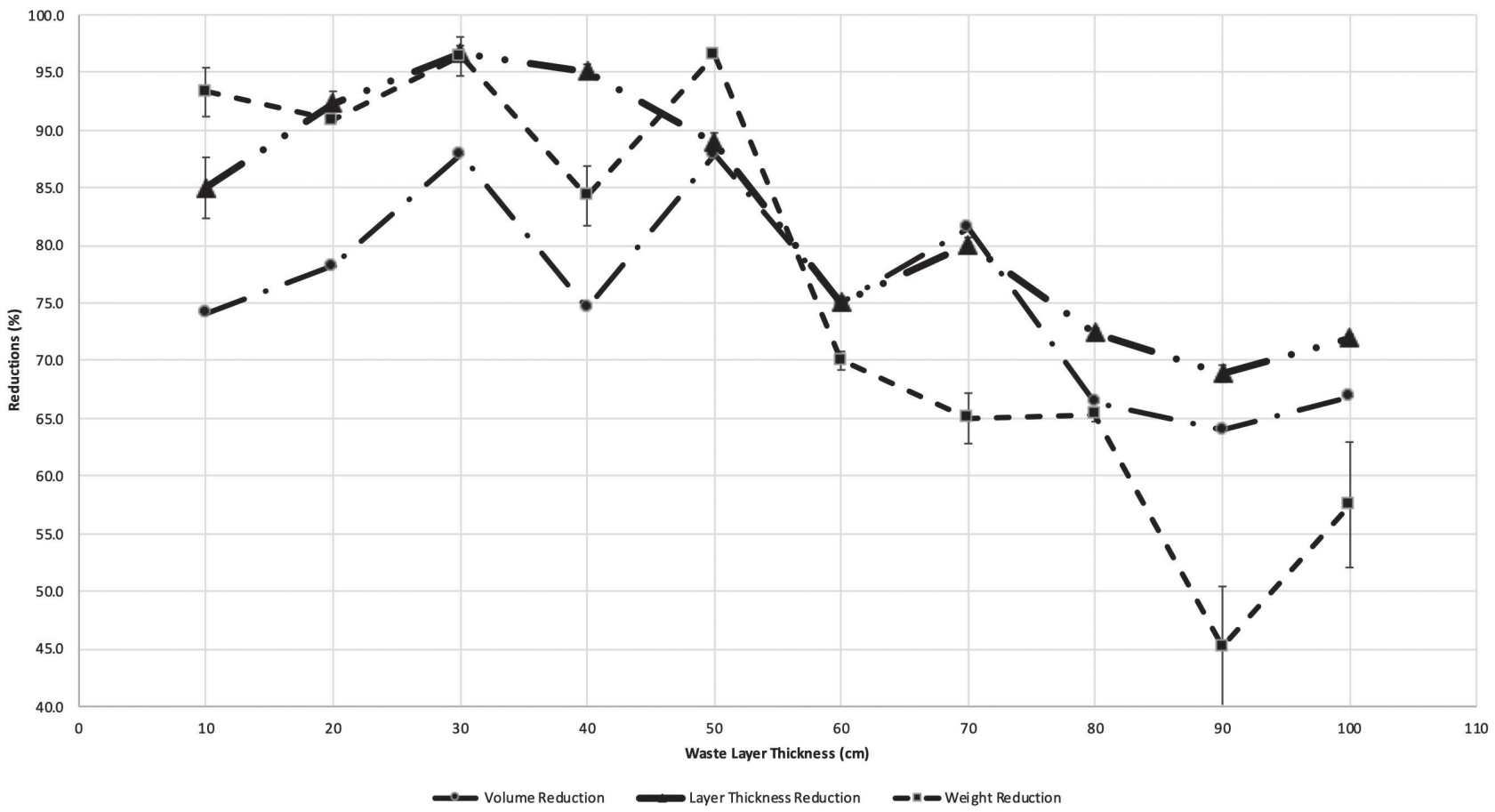

Fig. 1. Waste layer thickness reduction (\%), waste volume reduction (\%) and waste dry weight reduction (\%) during BSFL treatment of 15 days in waste layers with thickness from $10-100 \mathrm{~cm}$ : values represent mean $(\mathrm{n}=3) \pm$ standard deviation $(\mathrm{SD})$. 
waste layers. All samples $(20-100 \mathrm{~cm})$ WLT showed significant differences in WLT reduction as compared to control $(10 \mathrm{~cm})$ thickness where $(p<0.05)$. However, reductions in samples 20,30 and $40 \mathrm{~cm}$ thickness do not differed significantly (Tukey HSD test). Fig. 1 shows that till $50 \mathrm{~cm}$ thickness, WLT reduction was higher than control $(10 \mathrm{~cm})$ thick waste layer. WLT reduction in the $60-100 \mathrm{~cm}$ thick waste layer samples was found lower than the one observed in $10 \mathrm{~cm}$ thick waste sample. However, similar reductions were achieved in waste samples with $80 \mathrm{~cm}(72.5 \%)$ and $100 \mathrm{~cm}(72 \%)$ thickness (Tukey HSD test). The lower degree of waste reduction in layers with $60-100 \mathrm{~cm}$ thickness might be due to non-homogenous mixing as it was difficult to mix waste layers manually with increased thickness. This may result in lesser air circulation and even distribution of larvae in the waste layers. Thicker waste layers also exerted more pressure on the larvae in lower layers that may inhibit the larval movement and activities.

The day with $50 \%$ WLT reduction was considered a key performance indicator representing half of the reduction with respect to initial height. Fig. 2 shows that 50\% WLT was achieved in first 3 to 7 days in samples with $1100 \mathrm{~cm}$ thickness. Therefore, from waste management perspective, resolving the $50 \%$ problem in less than $30 \%$ of the time as required for $100 \%$ solution (15 days) is important for treating larger amounts of waste especially in cases where space constraints exist.

Volumetric reduction varied between $87.9 \%$ (SD 4.37) and 63.9\% (SD 3.46) (Table 1). Highest reduction of $87.9 \%$ was achieved at 30 and $50 \mathrm{~cm}$ WLT. The volumetric reduction achieved till $70 \mathrm{~cm}$
WLT was higher than control $10 \mathrm{~cm}$ sample (Fig. 1). At $100 \mathrm{~cm}$ WLT volumetric reduction (66.9\%) does not vary significantly from control $10 \mathrm{~cm}$. Previous studies on black soldier fly larvae biowaste treatment do not provide data on waste thickness and volumetric reductions.

\section{Waste Reduction Efficiency by Weight on Dry Basis (65.5-78.9)}

Waste dry weight reduction varied between 96.5 (SD 0.20) for $50 \mathrm{~cm} \mathrm{WLT} \mathrm{and} \mathrm{45.2 \%} \mathrm{(SD} \mathrm{5.20)} \mathrm{for}$ $90 \mathrm{~cm}$ thickness (Table 2, Fig. 2). The WLT 50 and $30 \mathrm{~cm}$ showed similar and maximum reductions of 96.5 and $96.4 \%$ respectively which do not have significant difference from control $10 \mathrm{~cm}$ (Tukey HSD test). It was found that dry weight waste reduction efficiency was higher in waste layers with thicknesses till $50 \mathrm{~cm}$ while in $50-100 \mathrm{~cm}$ thick waste layers the efficiency was found to be comparatively lower. The maximum dry weight reduction efficiency was found to be at $30 \mathrm{~cm}$ thick layer. Therefore, if a facility intends to achieve higher dry weight reductions the optimum waste layers thickness could reach up to $50 \mathrm{~cm}$. However, if purpose is to reduce waste weight or volume for efficient waste handling in a limited time, the layer thickness may be increased up to $100 \mathrm{~cm}$.

Fig. 1 shows that the waste dry weight reduction and WLT reduction roughly followed the same trend till $50 \mathrm{~cm}$ WLT. However, between 50-100 cm WLT waste dry weight reduction efficiency drops below WLT reduction rate. This might be due to larger amounts of

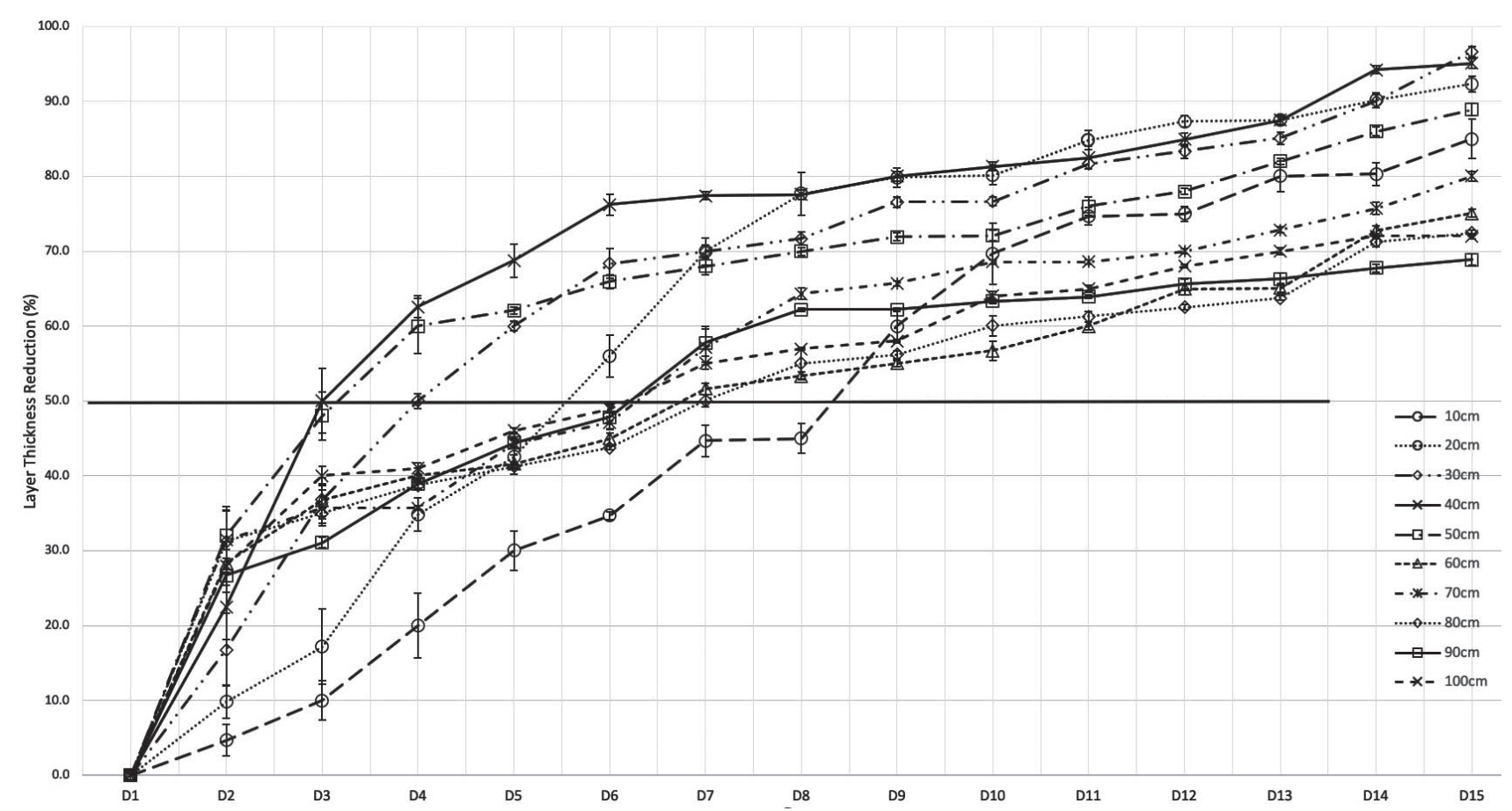

Fig. 2. Waste layer thickness reduction (\%) with respect to BSFL treatment time of 15 days in waste samples with layer thickness of 10 to $100 \mathrm{~cm}$ : values represented as mean $(\mathrm{n}=3)$. Horizontal line $(-)$ shows $50 \%$ reduction in waste layer thickness. 
Table 1. Waste Layer Thickness Reduction, Day of 50\% Reduction, Waste volumetric reduction Mean values $(\mathrm{n}=3) \pm$ standard deviation $(\mathrm{SD})$ with same letter in a column do not differ significantly where $(\mathrm{p}<0.05)$.

\begin{tabular}{|c|c|c|c|c|c|}
\hline \multirow{2}{*}{$\begin{array}{l}\text { Waste sample thickness } \\
\qquad(\mathrm{cm})\end{array}$} & \multicolumn{2}{|c|}{ Waste layer thickness reduction (\%) } & \multirow{2}{*}{$\begin{array}{c}50 \% \text { thickness reduction } \\
\text { day }\end{array}$} & \multicolumn{2}{|c|}{ Waste volumetric reduction (\%) } \\
\hline & Mean & $\mathrm{SD}$ & & Mean & SD \\
\hline 10 & $85.0 \mathrm{~d}$ & 2.65 & 9th & 74.1adfg & 2.87 \\
\hline 20 & $92.3 \mathrm{a}$ & 1.04 & 6th & $78.2 \mathrm{ab}$ & 3.97 \\
\hline 30 & $96.7 \mathrm{a}$ & 0.67 & 4th & $87.9 \mathrm{bc}$ & 4.37 \\
\hline 40 & $95.1 \mathrm{a}$ & 0.63 & $3 \mathrm{rd}$ & 74.6afg & 3.82 \\
\hline 50 & $88.9 \mathrm{e}$ & 0.83 & 4th & $87.9 \mathrm{bc}$ & 2.61 \\
\hline 60 & $75.1 \mathrm{~b}$ & 0.51 & 7th & $75.0 \mathrm{adfg}$ & 5.20 \\
\hline 70 & $80.0 \mathrm{f}$ & 0.64 & 7th & $81.5 \mathrm{abd}$ & 3.16 \\
\hline 80 & $72.5 \mathrm{bc}$ & 0.36 & 7th & 66.4ifh & 3.76 \\
\hline 90 & $68.9 \mathrm{~g}$ & 0.73 & 7 th & 64.0ikh & 3.46 \\
\hline 100 & $72.0 \mathrm{c}$ & 0.30 & 7th & $66.9 \mathrm{fgh}$ & 2.69 \\
\hline
\end{tabular}

residue in these samples (Fig. 3). The higher the residue, the lower would be the waste dry weight reduction. Similar trend can be observed in a study conducted on chicken feed decomposition using BSFL [21].

In another study on municipal organic waste treatment through BSFL, the maximum dry weight reduction achieved was $78.9 \%$ [15]. The reductions achieved up to $50 \mathrm{~cm}$ WLT were higher as compared to reductions in samples with $60-100 \mathrm{~cm}$ thickness and showed significant difference when compared with $10 \mathrm{~cm}$ (Fig. 1). At $90 \mathrm{~cm}$ WLT, lowest dry weight reduction was achieved which differed significantly from control $10 \mathrm{~cm}$ and all other samples (Table 2). Material reduction achieved in the present study was higher than mentioned for fruit and vegetable waste, banana peelings, food waste, pig manure, dog food, dairy manure, fecal sludge, and brewer's waste [20, 21, 23-26]. This might be due to regular mixing (on daily basis) of waste and larvae in order to allow air circulation and equal distribution of BSFL in waste sample, which if not done may lead to their accumulation in colonies and corners depriving many of food. Fruit and vegetable waste have greater dry matter reductions as compared to other types of organic wastes due to the higher amounts of easily available carbon content in it [20].

However direct effect of mixing and forced aeration has not been determined in this study. A study also reported higher weight reductions for samples that received daily complete mixing of fresh waste with the residue [15].

\section{Mass Balance}

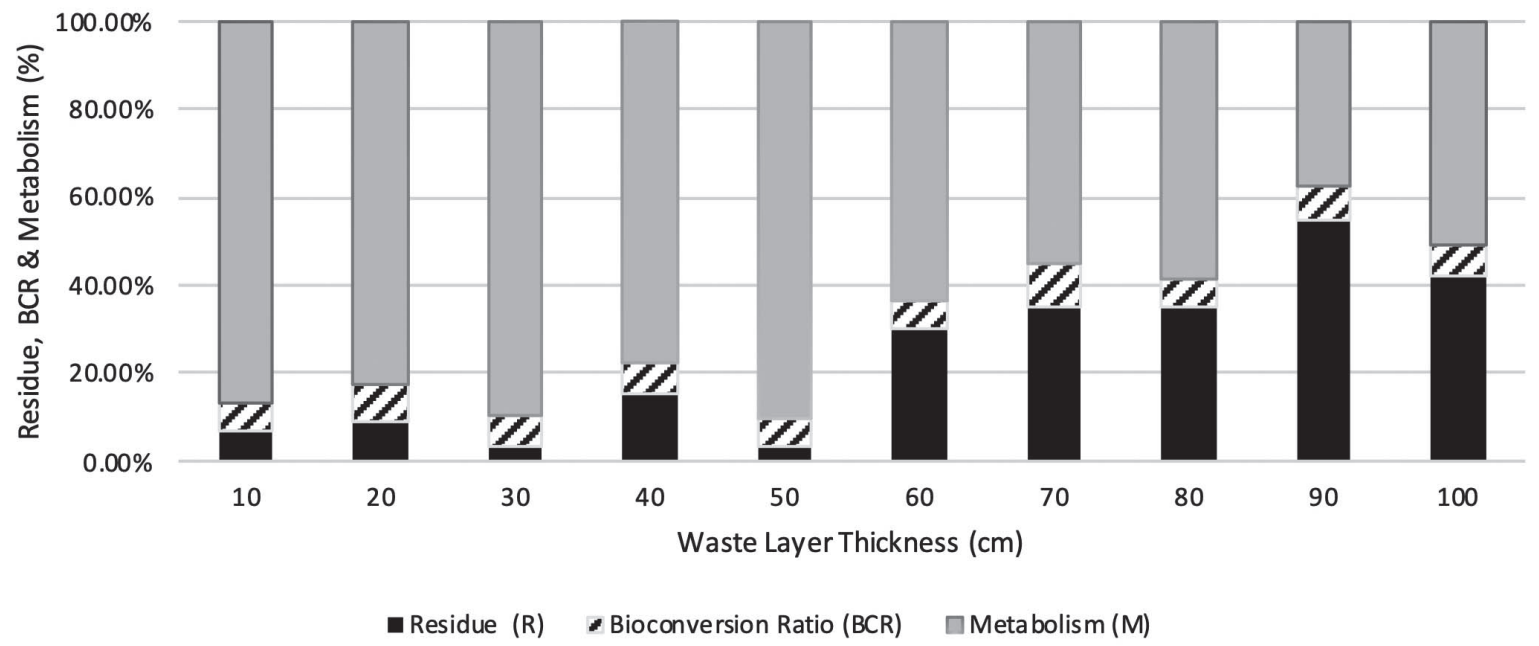

Fig. 3. Relative proportion of organic waste converted to residue R (\%), prepupal biomass (\%) (BCR), and metabolized waste (M\%) on feeding BSFL to waste samples with layer thickness $10-100 \mathrm{~cm}$ : values presented as mean $(\mathrm{n}=3)$. Metabolism is the difference between final dry weight of larvae (residue) and prepupal biomass and the total amount of waste added during its entire feeding stage[20]. 
Table 2. Waste dry weight reduction, residue (final dry wt of larvae), final prepupal dry weight. Mean values $(\mathrm{n}=3) \pm$ standard deviation $(\mathrm{SD})$ with same letter in a column do not differ significantly where $(\mathrm{p}<0.05)$.

\begin{tabular}{|c|c|c|c|c|c|c|c|c|c|c|}
\hline $\begin{array}{l}\text { Waste sample } \\
\text { layer thickness }\end{array}$ & Waste & 1 dry wt & Residu & (ry wt) & $\begin{array}{r}\text { Waste we } \\
\text { on } \mathrm{d}\end{array}$ & $\begin{array}{l}\text { duction } \\
\text { is }\end{array}$ & $\begin{array}{r}\text { Final Dr } \\
\text { BS }\end{array}$ & wt of 1 & Prepup & mass \\
\hline \multirow{2}{*}{$(\mathrm{cm})$} & \multicolumn{2}{|c|}{$(\mathrm{kg})$} & \multicolumn{2}{|c|}{$(\mathrm{kg})$} & \multicolumn{2}{|c|}{$(\%)$} & \multicolumn{2}{|c|}{ (g) } & \multicolumn{2}{|c|}{$(\mathrm{kg})$} \\
\hline & Mean & SD & Mean & SD & Mean & SD & Mean & SD & Mean & $\mathrm{SD}$ \\
\hline 10 & 49.0 & 2.29 & 3.28 & 0.93 & $93.3 \mathrm{ac}$ & 2.12 & $0.033 \mathrm{ac}$ & 0.0017 & 3.21 & 0.16 \\
\hline 20 & 47.0 & 2.29 & 4.28 & 0.23 & $90.9 \mathrm{abc}$ & 0.17 & $0.041 \mathrm{a}$ & 0.0027 & 4.01 & 0.26 \\
\hline 30 & 15.0 & 0.26 & 0.55 & 0.26 & $96.4 \mathrm{ac}$ & 1.69 & $0.031 \mathrm{bc}$ & 0.0017 & 1.01 & 0.05 \\
\hline 40 & 16.2 & 0.76 & 2.52 & 0.3 & $84.3 \mathrm{~b}$ & 2.59 & $0.035 \mathrm{a}$ & 0.0031 & 1.13 & 0.10 \\
\hline 50 & 17.7 & 1.53 & 0.62 & 0.06 & $96.5 \mathrm{c}$ & 0.23 & $0.033 b c$ & 0.0031 & 1.06 & 0.10 \\
\hline 60 & 25.2 & 1.56 & 7.57 & 0.29 & $70.0 \mathrm{~d}$ & 0.80 & $0.033 \mathrm{a}$ & 0.0018 & 1.63 & 0.09 \\
\hline 70 & 23.2 & 0.31 & 8.13 & 0.54 & $65.0 \mathrm{de}$ & 2.19 & $0.047 \mathrm{ad}$ & 0.0031 & 2.31 & 0.15 \\
\hline 80 & 24.5 & 1.15 & 8.51 & 0.53 & $65.3 \mathrm{de}$ & 0.59 & $0.032 \mathrm{bc}$ & 0.0023 & 1.58 & 0.11 \\
\hline 90 & 22.3 & 1.15 & 12.16 & 0.59 & $45.2 \mathrm{f}$ & 5.21 & $0.036 \mathrm{a}$ & 0.0032 & 1.74 & 0.15 \\
\hline 100 & 23.5 & 1.15 & 9.94 & 0.85 & $57.5 \mathrm{e}$ & 5.44 & $0.034 \mathrm{a}$ & 0.0056 & 1.64 & 0.27 \\
\hline
\end{tabular}

Prepupal Biomass, Bioconversion Rate (BCR), Residue (R) and Metabolism (M)

Prepupal dry weight $(0.048-0.031 \mathrm{~g} / \mathrm{larvae})$ in all waste layer thicknesses does not vary significantly from control $10 \mathrm{~cm}$ WLT, verified by Tukey HSD test (Table 2). Highest prepupal dry weight was achieved in $70 \mathrm{~cm}$ WLT. These values are lower as compared to those reported for BSFL fed on municipal organic waste. In general, prepupal weight is lower for fruit and vegetable waste because of low nitrogen content [20].

Fig. 3 shows that bioconversion rate (BCR) ranged between 6.01 (SD 0.34)-9.94\% (SD 0.66) which is a small fraction of organic waste transformation into prepupal biomass. The results are comparable with the reported $1.1 \%$ to $7.3 \% \mathrm{BCR}$ for fruit, manure and rejected slurry [19]. However, another study reported much lower $4.1 \%$ BCR for fruit and vegetable waste [20]. BCR values for different waste layer thicknesses did not show any honestly significant difference when compared to control $10 \mathrm{~cm}$ WLT except $70 \mathrm{~cm}$ thick layer (Tukey HSD test). The highest BCR measured was for $70 \mathrm{~cm}$ WLT (Fig. 3). The overall metabolized waste was greater than the residual waste which was a combination of digested and undigested food by larvae. From waste management perspective, it would be beneficial if some part of waste becomes larval biomass, and larval activity leaves small portion as residue and major portion remains as metabolized waste. This would leave less amount of residue to be further transported or disposed. This situation is contrary to the study on chicken feed BSFL conversion under control laboratory environmental conditions [21]. BCR could be affected by several factors: waste composition, number of larvae, environmental conditions (temperature/humidity) and feeding mode [19, 25]. Fruit and vegetable market waste may result in higher dry matter reductions but lower conversions to prepupal biomass. This is mainly because of high moisture and low nitrogen content (necessary for larvae body makeup) present in it [19, 20]. Biowaste treatment was performed under ambient temperatures which were quite high as compared to required optimum temperatures of $25-32^{\circ} \mathrm{C}$ for achieving higher BCR [14, 27].

\section{Conclusions}

Though BSFL related guidelines recommend use of maximum WLT of $5-10 \mathrm{~cm}$, it was found in this study that BSFL could successfully be fed to organic waste layers having thickness of greater than $10 \mathrm{~cm}$ and increased till $100 \mathrm{~cm}$. If even $20 \mathrm{~cm}$ is maximum thickness used, it requires an area of $8 \mathrm{~m}^{2}$ to treat 1 ton of organic waste. However, in field, maximum height cannot be restricted to $20 \mathrm{~cm}$ only as it would require huge surface area for large amounts of incoming waste. The study experimented with different heights between $10-100 \mathrm{~cm}$ implying $100 \mathrm{~cm}$ as maximum height would require an area of $1.6 \mathrm{~m}^{2}$ to treat 1 ton of organic waste i.e. 5 folds reduction in required surface area for treating same amount of waste and thus reducing space foot print of the BSFL treatment approach.

In cases where enough land is not available to attain maximum reduction by letting waste stay for longer time period, $50 \%$ reduction in comparatively less time may provide an option for quicker cycles of waste treatment. Waste layer with thickness of $50 \mathrm{~cm}$ can be used in BSFL organic waste treatment as it resulted in greater WLT reduction, early $50 \%$ thickness 
reduction, more waste dry weight and volume reduction as compared to widely recommended $10 \mathrm{~cm}$ thick layer. If BSFL waste treatment is applied at decentralized locations i.e. neighborhood level, significant reductions in waste weight and volume would be helpful in increasing carrying capacity of a certain vehicle, for further transport and decreasing space requirement at a disposal site leading to less transportation, handling and disposal costs.

As per findings of this study, maximum reductions in WLT, dry weight and volume was achieved if BSFL was fed to $30 \mathrm{~cm}$ thick waste layer which still can save 3 folds of land as compared to widely recommended $10 \mathrm{~cm}$ thick layer. In case of lack of land availability and to create speedy waste reductions in large quantities $50 \%$ WLT reduction might be a good key performance indicator. In such cases, maximum reductions in first 2-4 days of waste treatment would be beneficial which happened in $90 \%$ of the waste samples. Financial analysis will also be required for the viability of $50 \%$ reduction on basis of land and transportation cost savings.

Increased waste thickness did not affect larval weight gain and BCR values much. Both were less as compared to the maximum achievable values reported in literature. It is important to note here that this study was done from waste management perspective and achieving higher BCR and massive larval harvest was not of key concern. Moreover, if BSFL is fed to thicker layers of waste up to $50 \mathrm{~cm}$ then it might result in significant waste reductions by generating minimum residue and maximum metabolism as compared to $10 \mathrm{~cm}$ thick waste sample and this would create more space for incoming waste to be treated and less residue to be transported further. Though the waste thickness and dry matter reduction, in layers with thickness between 60 and $100 \mathrm{~cm}$ and volumetric reduction between $80-100 \mathrm{~cm}$ was lower than the one observed in $10 \mathrm{~cm}$ thick layer, still considerable reductions of 72, 57.7 and $66.9 \%$ was noted respectively.

This study provides a doable option for large amounts of organic waste to be treated using BSFL with limited surface area and time available.

\section{Acknowledgements}

The study was conducted at the Urban Unit Lahore's project site in Sahiwal city. The researcher is grateful to the Urban Unit and its SWM team for providing crucial support during the study. A special gratitude is extended to EAWAG, Switzerland and Forward, Indonesia for providing necessary intensive operational training and guidance.

This research did not receive any specific grant from funding agencies in the public, commercial, or not-forprofit sectors.

\section{Conflict of Interest}

The authors declare no conflict of interest.

\section{References}

1. KUMAR S., NEGI S., MANDPE A., SINGH, R.V., HUSSAIN A. Rapid Composting Techniques in Indian Context and Utilization of Black Soldier Fly for Enhanced Decomposition of Biodegradable Wastes - A Comprehensive Review. J. Environ. Manage. 227, 189, 2018.

2. MERTENAT A., DIENER S., ZURBRÜGG C. Black Soldier Fly biowaste treatment - Assessment of global warming potential. Waste. Manage. 84,173, 2019.

3. KINGDOM U., REPORT S.R., COUNCIL A. Technical team. Water.

4. MASOOD M., BARLOW C.Y. Framework for integration of informal waste management sector with the formal sector in Pakistan. Waste. Manage. Res. 3(10 SUPPL), 93, 2013.

5. AHMED N., ZURBRUGG C. Urban organic waste management in Karachi, Pakistan. Sustain. Environ. Sanit. Water Serv, Proc. 28 ${ }^{\text {th }}$ WEDC Conf. January, 2002.

6. JEHANGIR A. Waste to Energy Potential in Pakistan and Its Comparison with the Situation in Europe. Adv. Recycling. Waste. Manag. 03 (2), 2, 2018.

7. ZURBRÜGG C., DORTMANS B., FADHILA A., VERSTAPPEN B., DIENER S. From Pilot To Full Scale Operation of a Waste-To-Protein Treatment Facility. Detritus. 1, 18, 2018.

8. GOLD M., TOMBERLIN J.K., DIENER S., ZURBRÜGG C., MATHYS A. Decomposition of Biowaste Macronutrients, Microbes, and Chemicals in Black Soldier Fly Larval Treatment: A Review. Waste. Manage. 82, 302, 2018.

9. DIENER S., ZURBRÜGG C., ROA-GUTIÉRREZ F., NGUYEN D.H., MOREL A., KOOTTATEP T., TOCKNER K. Black Soldier Fly Larvae for Organic Waste Treatment - Prospects and Constraints. Proceedings of the WasteSafe, 2 February, 52, 2011.

10. JOYCE J.A. SHEPPARD D.C., KISER B.C., TOMBERLIN J.K., SUMNER S.M. Rearing Methods for the Black Soldier Fly (Diptera: Stratiomyidae). J. Med. Entomol. 39 (4), 695, 2009.

11. DORTMANS B.M.A., Diener S., VERSTAPPEN B. Black Soldier Fly Biowaste Processing, $1^{\text {st }}$ ed.; Eawag (Swiss Federal Institute of Aquatic Science and Technology): Dubendorf, Switzerland, 100, 2017.

12. SPRANGHERS T., MICHIELS J., VRANCX J., OVYN A. Gut antimicrobial effects and nutritional value of black soldier fly (Hermetia illucens L.) prepupae for weaned piglets. Anim. Feed. Sci. Technol. 235, 35, 2018.

13. NGUYEN T.T.X., TOMBERLIN J.K., VANLAERHOVEN S. Ability of Black Soldier Fly (Diptera: Stratiomyidae) Larvae to Recycle Food Waste. Environ. Entomol. 44 (2), 406, 2015.

14. RIUJI C., DIENER S., ZABALETA I., MERTENAT A., ZURBRÜGG C. Treatment technologies for urban solid biowaste to create value products: a review with focus on low- and middle-income settings. Rev. Environ. Sci. Biotechnol. 16 (1), 81, 2017. 
15. DIENER S., STUDT SOLANO N.M., ROA GUTIÉRREZ F., ZURBRÜGG C., TOCKNER K. Biological treatment of municipal organic waste using black soldier fly larvae. Waste. Biomass. Valori. 2 (4), 357, 2011.

16. BULLOCK N., CHAPIN E., EVANS A., ELDER B., GIVENS M., JEFFAY N., PIERCE B., ROBINSON W. The black soldier fly How- to- guide. Biosyst. UNC Institute for The Environment, 2013.

17. ČIČKOVÁ H., NEWTON G.L., LACY R.C., KOZÁNEK M. The use of fly larvae for organic waste treatment. Waste. Manage. 35, 68, 2015.

18. CAMMACK, J.A., TOMBERLIN, J.K. The impact of diet protein and carbohydrate on select life-history traits of the black soldier fly Hermetia illucens (L.) (Diptera: Stratiomyidae). Insects. 8 (2), 56, 2017.

19. MUTAFELA., RICHARD. High Value Organic Waste Treatment via Black Soldier Fly Bioconversion. Master thesis, 2015.

20. LALANDER C., DIENER S., ZURBRÜGG C., VINNERÅS B. Effects of feedstock on larval development and process efficiency in waste treatment with black soldier fly (Hermetia illucens L.). J. Clean. Prod. 208, 211, 2019.

21. DIENER S., ZURBRÜGG C., TOCKNER K. Conversion of organic material by black soldier fly larvae: Establishing optimal feeding rates. Waste. Manag. Res. 27 (6), 603, 2009.
22. BRITS D., TECHNOLOGIES A., VILLET M.H., Improving feeding efficiencies of black soldier fly larvae, Hermetia illucens (L., 1758) (Diptera: Stratiomyidae: Hermetiinae) through manipulation of feeding conditions for industrial mass rearing. Biology. 2017.

23. REHMAN K., REHMAN A., CAI M., ZHENG L. Conversion of mixtures of dairy manure and soybean curd residue by black soldier fly larvae (Hermetia illucens L.). J. Clean. Prod. 154, 366, 2017.

24. LALANDER C.H., DIENER S., MAGRI M.E., ZURBRÜGG C. Faecal sludge management with the larvae of the black soldier fly (Hermetia illucens) - From a hygiene aspect. Sci. Total. Environ. 458-460, 312, 2013.

25. LALANDER C.H., FIDJELAND J., DIENER S., ERIKSSON S., VINNERÅS B. High waste-to-biomass conversion and efficient Salmonella spp. reduction using black soldier fly for waste recycling. Agron. Sustain. Dev. 35 (1), 261, 2014.

26. NYAKERI E.M., OGOLA H.J.O., AYIEKO M.A., AMIMO F.A. Valorisation of organic waste material: Growth performance of wild black soldier fly larvae (Hermetia illucens) reared on different organic wastes. J. Insects. Food. Feed. 3 (3), 193, 2017.

27. TOMBERLIN J.K., ADLER P.H., MYERS H.M. Development of the Black Soldier Fly (Diptera: Stratiomyidae) in Relation to Temperature. Environ. Entomol. 38 (3), 930, 2009. 
